\title{
Yetişkin bireylerin sindirim sistemi problemlerinde besin ve bitkisel ürün kullanım durumları
}

\author{
Conditions of use of food and vegetable products in the adults having digestive system problems
}

\author{
(DDilan BARLIN ${ }^{1}$, (D)Aydan ERCAN² \\ Ufuk Üniversitesi Dr. Rıdvan Ege Hastanesi, 'Beslenme ve Diyet Birimi, Ankara \\ Trakya Üniversitesi Sağlık Bilimleri Fakültesi, ²Beslenme ve Diyetetik Bölümü, Edirne
}

Giriş ve Amaç: Bu çalışma yetişkin bireylerin sindirim sistemi problemlerinde kullandıkları besin ve bitkisel ürünleri saptamak amacıyla gerçekleştirilmiştir. Gereç ve Yöntem: Araştırma örneklemi, Aralık 2017-Mart 2018 tarihleri arasında Mersin ilinde bulunan bir devlet hastanesine herhangi bir nedenle başvurmuş, aynı hastanede görevli hekimler tarafından ilaç reçeteleri düzenlenmiş ve ilaç reçetelerini temin etmek amacıyla bir eczaneye gelmiş olan 18-80 yaş arası 196 yetişkin bireyden oluşmaktadır. Çalışmada veri toplama aracı olarak araştırmacı tarafından hazırlanan anket formu kullanılmıştır. Çalışma verileri SPSS 17.0 paket programı ile uygun istatistiksel yöntemler kullanılarak değerlendirilmiştir. Bulgular: 196 yetişkin bireyin bulunduğu bu çalışmada 120 (\%61.2) birey sık karşılaştığı sindirim sistemi yakınması olduğunu bildirmektedir. Bu bireylerin 57'si (\%53.8) sindirim sistemi yakınmalarında besin ve bitkisel ürün kullanımı olduğunu bildirmiştir. 63'ü (\%70) ise sindirim sistemi yakınmalarında besin ve bitkisel ürün kullanmadığını bildirmiştir. 76 bireyin (\%38.8) sık yaşadığı sindirim sistemi yakınması bulunmamaktadır. Ancak yakınması olmayan bireylerin 49'u (\%46.2) sindirim sistemi yakınmalarında besin ve bitkisel ürün kullanımı olduğunu bildirmiştir. Sonuç: Sindirim sistemi rahatsızlıkları için, etraftan duyulan, medya veya diğer kitle iletişim araçları üzerinden etkinliği kanıtlanmamış, bitkisel ürünler veya bitkiler kullanmak yerine fiziksel aktiviteyi arttırmak, dengeli ve düzenli beslenmek, yeterli su tüketimini sağlamak, doğru pişirme tekniklerini kullanmak, beslenme alıskanlıklarını düzenlemek gibi basit yaşam tarzı değişiklikleri ile üstesinden gelmek sağlıklı bir yaşam için temel oluşturacaktır.

Anahtar kelimeler: Bitkisel ürün, geleneksel tedavi, gastrointestinal sistem hastalıkları, beslenme, sindirim sistemi

\section{GíRiş}

Gastrointestinal sistem (GIS); organizmanın katı ve sıvı besinlerin sindirim kanalında ilerlemesi sırasında su, vitamin ve minerallerle birlikte karbonhidrat, protein ve yağların emilerek kan dolaşımına geçebileceği küçük yapı taşlarına parçalandığı kanal olması nedeniyle büyük önem taşımaktadır (1). Yeterli ve dengeli beslenme; canlıların büyümesi, gelişmesi, yaşamlarını devam ettirebilmeleri ve yaşamsal faaliyetlerini en iyi şekilde yapabilmeleri için gerekli besin öğelerinin alınmasıdır (2). Bireyin sağlığını ve

Iletişim: Aydan ERCAN

Trakya Üniversitesi Sağlık Bilimleri Fakültesi, Beslenme ve Diyetetik Bölümü, Edirne

Tel: +90 2842133042 •E-mail: aydanercan@trakya.edu.tr
Background and Aims: This study was conducted to determine the nutritional and herbal products used by adult individuals for their digestive system problems. Materials and Methods: The study sample consisted of 196 adult patients who were between 18 and 80 years old, admitted to a state hospital in Mersin Province for any reason between December 2017 and March 2018, prescribed a medication by doctors in the same hospital, and asked to go to a pharmacy to obtain prescriptions for medication. A questionnaire form prepared by the researcher was used as a data collection tool, and data were evaluated using appropriate statistical methods via SPSS 17.0. Results: Of the 196 adults included in this study, 120 (61.2\%) reported frequent gastrointestinal complaints. Of these individuals, 57 (53.8\%) presented with digestive system complaints due to food and plant products, 63 (70\%) stated that they did not blame food and herbal products for their digestive system complaints, and 76 (38.8\%) had no gastrointestinal complaints. However, 49 (46.2\%) of the uncomfortable individuals mentioned that they used food and herbal products that likely caused their digestive system complaints. Conclusions: As a result, for digestive system disorders, no proven activity on media or other mass communication media was observed. Using plant products or plants, increasing physical activity, eating balanced and regular food, consuming a sufficient amount of water, utilizing correct cooking techniques, and regulating dietary habits coming from above with simple lifestyle changes will be the basis for having a healthy lifestyle.

Keywords: Herbal product, traditional treatment, gastrointestinal system diseases, nutrition, digestive system

yaşamını sürdürebilmesinde yeterli ve dengeli beslenme kadar sağlıkı bir sindirim sistemine sahip olmak da büyük önem taşımaktadır. Ağızdan anüse kadar sindirim sisteminde görülebilen pek çok hastalı̆ın türüne, görüldüğü bölgeye ve bireysel faktörlere bağı olarak uygulanacak beslenme tedavi ilkeleri de farklılklar göstermektedir. Medikal tedavinin yanı sıra beslenme tedavisinde temel amaç; akut veya kronik seyredebilen hastalık süresince hastanın komplikasyonlardan korunması için en uygun

Barlin D, Ercan A, et al. Conditions of use of food and vegetable products in the adults having digestive system problems. The Turkish Journal of Academic Gastroenterology 2020;19:31-37. DOI: 10.17941/agd.708506

Geliş Tarihi: 19.08.2019 • Kabul Tarihi: 18.02.2020 
beslenme programını hazırlamak ve bu süre içinde yeterli ve dengeli beslenmesini sağlayabilmektir. Bu amaçla, bazı besinler diyetten tamamen elimine edilebileceği gibi, tüketilen bazı besinlerin de miktar ve pişirme yöntemlerinin değiştirilmesi gündeme gelebilir $(1,3,4)$. Sindirim sistemi problemleri ve hastalıkları, günümüzde en sık rastlanan sağlık sorunları arasında yer almaktadır. Diğer vücut sistemlerini etkileyen hastalıklardan farklı olarak gastrointestinal hastalıklar doğrudan besin alımını, sindirimini ve emilimini etkilemesiyle hastalar için yüksek nutrisyonel risk oluşturmaktadır $(5,6)$. Sindirim sistemi hastalıkları ve problemlerini azaltmak amacıyla bireysel olarak uygulanan kulaktan dolma, bilimsel kanıta dayalı olmayan geleneksel yöntemler beklentilerin aksine bu hastalıkların şiddetini azaltabileceği gibi arttırabilmektedir. Geleneksel ve tamamlayıcı tedavi, fiziksel ve ruhsal hastalıklardan korunma, iyileştirme veya tedavi etmede kullanılan farkIı kültürlere özgü teori, inanç ve tecrübelere dayalı, bilgi, beceri ve uygulamaların bütünüdür. Tamamlayıcı ve geleneksel tedavi, sıklıkla yaşam kalitesini yükseltmek, semptomları ve ilaçların yan etkilerini azaltmak, fiziksel ve psikolojik destek sağlamak amacıyla uygulanmaktadır (7). Ancak, genellikle tamamlayıcı ve/veya geleneksel tedavi ile aynı olduğu sanılan alternatif tedavi ise, bilimsel tıbbi uygulamalar yerine yapılan ve etkisi bilimsel olarak kanıtlanmamış tedavi yöntemlerini içermektedir (8). Tamamlayıcı, geleneksel ve alternatif tedavi uygulamaları ülkenin coğrafi konumuna, etnik kökenine, eğitim durumu ve sosyoekonomik faktörlere ve dini inanışlara göre farklılıklar göstermektedir. Bu çalışma, yetişkin bireylerin sindirim sistemi problemlerinde kullandıkları besin desteği ve bitkisel tedavi yöntem ve uygulamalarının saptanması amacıyla yürütülmüştür.

\section{GEREÇ ve YÖNTEM}

Bu çalışma, tanımlayıcı ve durum saptama çalışması olarak planlanmış olup Aralık 2017-Mart 2018 tarihleri arasında Mersin ilinde bulunan bir devlet hastanesine herhangi bir nedenle başvurmuş, aynı hastanede görevli hekimler tarafından ilaç reçeteleri düzenlenmiş ve ilaç reçetelerini temin etmek amacıyla hastaneye en yakın olan bir eczaneye gelmiş olan, 18-80 yaş arası 196 yetişkinden oluşmaktadır. Çalışmanın verileri, araştırmacı tarafından geliştirilen anket formunun, yüz yüze görüşme tekniği kullanılarak uygulanmasıyla toplanmıştır. Anket formu sosyo-demografik özellikler, sağlık durumu, beslenme alışkanlıkları, geleneksel tedavi hakkındaki bilgiler ile bireylerin sindirim sistemi problemlerinde bitkisel ilaç ve besin kullanımına yönelik tutum ve davranışlarını içermektedir. Çalışma verileri SPSS 17.0 paket programı kullanılarak analiz edilmiş ve değerlendirilmiştir.

\section{BULGULAR}

Araştırma kapsamına alınan 196 bireyin, 74'ü erkek (\%37.8), 122'si kadındır (\%62.2). Katııımcıların yaşları 1880 yıl arasında değişmekte olup, kadınların yaş ortalamaları 44.9 \pm 14.2 yıldır. Kadınların 36'sı (\%29.5), erkeklerin 23 'ü (\%31.1) lisans mezunudur. Kadınların 75'i (\%61.5), erkeklerin 45'i (\%60.8) GiS şikayeti bulunduğunu beyan etmişlerdir $(p<0.05)$. Katılımcıların beyanlarına bakıldığında şişkinlik, mide yanması ve konstipasyonun en sık karşılaşılan şikayetler olduğu görülmektedir (Tablo 1).

Sık yaşanılan sindirim sistemi rahatsızıkları bulunan 57 kişi (\%53.8) bu rahatsızlıklarda besin ve bitki kullandığını, 63 kişi (\%70) ise kullanmadığını belirtmiştir. Sık yaşadığı sindirim sistemi rahatsızlığı olmadığını belirtip, sindirim sistemi rahatsızlıklarında besin ve bitki kullananlar 49 kişi (\%46.2), kullanmayanlar ise 27 kişidir (\%30) (p $>0.05$ ). Bireylerin Gis yakınmalarına göre beslenme alışkanlıkları değerlendirildiğinde Gis şikâyeti olan 16 kişi (\%8.2) yeterli ve dengeli beslenmediğini (\%8.2), 86 kişi (\%43.9) genellikle yeterli ve dengeli beslendiğini, 18 kişi ise (\%9.2) her zaman yeterli ve dengeli beslendiğini belirtmektedir. Gis şikâyeti olan 11 (\%5.6) kişi hiç öğün atlamadığını, 6 kişi (\%5.6) her zaman öğün atladığını, 75 kişi (\%38.3) nadiren de olsa öğün atladığını, 28 kişi (\%14.3) her zaman öğün atladığını bildirmektedir. GiS şikâyeti olan 69 kişi (\%35.2) öğün saatlerinin düzenli olduğunu belirtirken, 51 kişi (\%26) öğün saatinin düzensiz olduğunu bildirmektedir. GiS şikayeti olan 73 kişi (\%37.2) atıştırmalık alışkanlığı olduğunu belirtmektedir. GiS şikayeti olan 57 (\%29.1) kişi ayda 1-2 kez de olsa dışarıdan yediğini bildirmektedir. Her gün dışarıda yediğini bildiren 18 (\%7.7) kişinin $15^{\prime}$ inde ise Gis şikayeti olduğu görülmektedir. Gis şikayeti olan 31 kişi (\%15.8) haftada 2-3 kez dışarıda yediğini belirtmektedir ve bu fark istatistiksel olarak anlamlı bulunmuştur ( $p<0.05$ ). Bireylerin ortalama su tüketimlerinin $1700 \mathrm{ml}$ olduğu görülmektedir (Tablo 2). Beslenme alışkanlıkları ile GiS şikayetleri karşılaştırıldı-

Tablo 1. Bireylerin en sık belirttiği GiS* yakınmalarının dağılımları

\begin{tabular}{lcc|}
\hline & N & $\%$ \\
\hline Şişkinlik & 45 & 23.0 \\
\hline Mide yanması & 34 & 17.3 \\
\hline Konstipasyon & 33 & 16.8 \\
\hline Reflü & 24 & 12.2 \\
\hline Gastrit & 20 & 10.2 \\
\hline Diyare & 6 & 3.1 \\
\hline
\end{tabular}

*Birden fazla seçenek işaretlenmiştir. 
Tablo 2. Bireylerin beslenme alışkanlıkları ile GiS yakınma durumlarının dağı̆ımı

\begin{tabular}{|c|c|c|c|c|c|c|c|c|}
\hline & & & Gis & yeti & & & & \\
\hline Beslenme Durumu & & & & & & & & \\
\hline Yeterli ve dengeli besl & nme durumu & $\mathbf{N}$ & $\%$ & $\mathbf{N}$ & $\%$ & $\mathbf{N}$ & $\%$ & \\
\hline & Hiç & 16 & 8.2 & 11 & 5.6 & 27 & 13.8 & \\
\hline & Genellikle & 86 & 43.9 & 47 & 24 & 133 & 67.9 & \\
\hline & Her zaman & 18 & 9.2 & 18 & 9.2 & 36 & 18.3 & $p=0.27$ \\
\hline Öğün atlama durumu & & & & & & & & \\
\hline & Hiç atlamıyor & 11 & 5.6 & 8 & 4.1 & 19 & 9.7 & \\
\hline & Nadiren atlıyor & 75 & 38.3 & 45 & 23 & 120 & 61.2 & \\
\hline & Sık sık atlıyor & 28 & 14.3 & 19 & 9.7 & 47 & 24.0 & $p=0.97$ \\
\hline & Her zaman atlıyor & 6 & 3.1 & 4 & 2 & 10 & 5.1 & \\
\hline Öğün saatleri düzenli $n$ & & & & & & & & \\
\hline & Düzenli & 69 & 35.2 & 49 & 25 & 118 & 60.2 & \\
\hline & Düzensiz & 51 & 26 & 27 & 13.8 & 78 & 39.8 & $p=0.33$ \\
\hline Atıştırma alışkanlığı vaı & mı? & & & & & & & \\
\hline & Var & 73 & 37.2 & 38 & 19.4 & 111 & 56.6 & \\
\hline & Yok & 47 & 24 & 38 & 19.4 & 85 & 43.4 & $p=0.13$ \\
\hline Ev dışı yeme sıklığı & & & & & & & & \\
\hline & Hiç & 7 & 3.6 & - & - & 7 & 3.6 & \\
\hline & Her gün & 15 & 7.7 & 3 & 1.5 & 18 & 9.2 & \\
\hline & Haftada 2-3 & 31 & 15.8 & 28 & 14.3 & 59 & 30.1 & $p=0.03^{*}$ \\
\hline & Haftada 4-5 & 10 & 5.1 & 8 & 4.1 & 18 & 9.2 & \\
\hline & Ayda 1-2 & 57 & 29.1 & 37 & 18.9 & 94 & 48.0 & \\
\hline Ortalama su tüketimi & & & & & $700 \mathrm{~m}$ & & & \\
\hline
\end{tabular}

ki kare testi uygulanmıştır.

ğında gruplar arasındaki farklar istatistiksel olarak önemli bulunmasa da GiS şikayeti olmayan kişilerin, olanlara göre daha sağlıklı ve doğru beslenme alışkanlıklarına sahip oldukları görülmüştür. Bireylerin yemek yeme hızına

Tablo 3. Yemek yeme hızına göre Gis şikâyeti bulunma durumu

\begin{tabular}{|lcccc|}
\hline & \multicolumn{4}{c}{ Gis Şikâyeti } \\
\hline Yeme Hızı & N & $\%$ & N & $\%$ \\
\hline Çok yavaş & 2 & 1.7 & 2 & 2.6 \\
\hline Yavaş & 10 & 8.2 & 5 & 6.6 \\
\hline Normal & 36 & 30 & 40 & 52.7 \\
\hline Hızlı & 53 & 44.3 & 27 & 35.5 \\
\hline Çok hızı & 19 & 15.8 & 2 & 2.6 \\
\hline Toplam & 120 & 100 & 76 & 100 \\
\hline
\end{tabular}

ki kare uygulanmıştır. $p=0.005$ * göre sindirim sistemi rahatsızlığı bulunma durumlarına bakıldığında, çok hızlı yediğini belirten 19 kişinin (\%9.7), hızlı yediğini belirten 53 kişinin (\%27) sindirim sistemi rahatsızlığı bulunmaktadır ve bu istatistiksel olarak anlamlı bulunmuştur ( $p<0.05$ ) (Tablo 3). Çalışmaya katılanların cinsiyetlerine göre sindirim sistemi şikayetlerinde besin ve bitki kullanımlarına bakıldığında, kadınların 55'i (\%45.1), erkeklerin 23'ü sindirim sistemi şikayetlerinde besin ve bitki kullanımları olduğunu belirtmektedir. Kadınların 67'si (\%54.9), erkeklerin 51'i (\%68.9) sindirim sistemi şikayetlerinde besin ve bitki kullanmadığını belirtmektedir. Bu fark istatistiksel olarak anlamlı bulunmuştur $(p<0.05)$. Sık yaşadığı GiS şikayetinin var olduğunu bildirenler mide yanması için; başta elma olmak üzere (\%4.2), maden suyu, leblebi, süt, nane, zencefil, ekmek kullandıklarını belirtmektedir. Sık yaşadığı GiS şikâyeti bulunmadığını bildiren kişiler ise mide yanması durumu yaşadıklarında; yine başta elma olmak üzere (\%19.7), maden suyu, leblebi, süt, nane ve ekmek kullanmaktadırlar. Sık yaşadığı GiS şikâyeti olan kişiler konstipasyon durumunda; başta kuru 


\begin{tabular}{|c|c|c|c|c|c|c|c|c|c|c|}
\hline & \multicolumn{2}{|c|}{ 1. sırada } & \multicolumn{2}{|c|}{ 2. sırada } & \multicolumn{2}{|c|}{ 3. sırada } & \multicolumn{2}{|c|}{ 4. sırada } & \multicolumn{2}{|c|}{ 5. sırada } \\
\hline & $\mathbf{N}$ & $\%$ & $\mathbf{N}$ & $\%$ & $\mathbf{N}$ & $\%$ & $\mathbf{N}$ & $\%$ & $\mathbf{N}$ & $\%$ \\
\hline Aile büyükleri & 57 & 29.1 & 46 & 23.5 & 31 & 15.8 & 30 & 15.3 & 32 & 16.3 \\
\hline Medya (tv, gazete, internet, dergi) & 40 & 20.4 & 49 & 25 & 35 & 17.4 & 46 & 23.5 & 26 & 13.3 \\
\hline Doktor & 64 & 32.6 & 24 & 12.2 & 51 & 26 & 25 & 12.8 & 32 & 16.3 \\
\hline Herbalistler & 25 & 12.8 & 40 & 20.4 & 28 & 14.3 & 59 & 30.1 & 44 & 22.4 \\
\hline Aktarlar & 10 & 5.1 & 37 & 18.9 & 52 & 26.5 & 36 & 18.3 & 61 & 30.5 \\
\hline
\end{tabular}

kayısı (\%15), zeytinyağı, kekik suyu, kuru incir kullanmaktadırlar. Sık yaşadığı Gis şikâyeti bulunmamasına rağmen, bazı katılımcılar da, konstipasyon durumunda kuru incir (\%13.2) başta olmak üzere, kuru kayısı, zeytin yağı, salatalık+su kullanımı belirtilmektedir. GiS şikayeti olduğunu bildirenler, diyare durumunda; başta haşlanmış patates (\%11.7), kuru Türk kahvesi-limon, muz, kola kullanımı belirtilmektedir. GiS şikayeti olmadığını belirtenlerse herhangi bir dönemde diyare olduklarında ise başta kuru Türk kahvesi-limon (\%27.6) ve muz (\%25), haşlanmış patates, kola, leblebi, yoğurt ve kuru çay kullanımını belirtmektedir. GiS şikayeti bildirenler şişkinlik durumunda ise başta maden suyu olmak üzere (\%12.5), rezene, kimyon, yeșil çay kullanmaktadır. Bireylerin geleneksel tedavi yöntemlerinde kullandıkları bilgi kaynaklarına bakıldığında 64 kişi (\%32.6) bilgi kaynağı olarak 1. sırada doktorları, 57 (\%29.1) kişi 1. sırada aile büyüklerini, 40 (\%20.4) kişi 1. sırada medyayı (tv, gazete, internet, dergi), 25 (\%12.8) kişi 1. sırada herbalistleri ve 10 (\%5.1) kişi 1. sırada aktarları kullandıklarını belirtmiştir. Ardından 49 (\%25) kişi bilgi kaynağı olarak 2. sırada medyayı, 46 (\%23.5) kişi 2. sırada aile büyüklerini ve 40 (\%20.4) kişi 2. sırada herbalistleri, 37 (\%18.9) kişi 2. sırada aktarları ve 24 (\%12.2) kişi 2. sırada doktorları kullandıklarını belirtmiştir. 61 kişi (\%30.5) en son sırada aktarları kullanmaktadır (Tablo 4).

Bireylerin kullandıkları bitkisel ürünleri temin etme yerlerine bakıldığında, 81 kişi (\%41.4) aktarlarda açıkta satılan (karışım, toz, çay) gibi ürünlerden, 53 kişi (\%27) eczaneden (kullanıma hazır tablet, toz ya da şurup), 51 kişi (\%26) aktarlarda kapalı kutuda satılan ürünlerden (karışım, toz, çay), 3 kişi (\%1.5) internetten, 5 kişi (\%2.6) halk pazarından temin ettiğini belirtirken, 3 kişi (\%1.5) herhangi bir ürün temin etmediğini belirtmiştir (Tablo 5).

\section{TARTIŞMA}

Bireylerin sağlığını ve dolayısıyla yaşam kalitesini olumsuz etkileyen gastrointestinal sistem hastalıkları toplumda yüksek bir prevalansa sahiptir. Fonksiyonel sindirim bozuklukları gastrointestinal bozuklukların en önemlileri olmakla birlikte sindirim sistemi şikâyeti ile sağlık kurumlarının gastroenteroloji bölümlerine başvuran hastaların yaklaşık \%50'sinin kronik gastrointestinal rahatsızlıkları olduğu belirtilmektedir. Hem enfeksiyonların bir sonucu hem de beslenme, stres gibi pek çok nedenle akut olarak diyare, reflü, gastroenterit, konstipasyon, şişkinlik gibi şikayetler ortaya çıkmaktadır (9). Barsak-beyin aksının da birbiriyle ilişkili olduğu da görülmektedir ve psikolojik etmenlerin gastrointestinal şikayetleri tetikleyebileceği belirtilmektedir (10). Gastrointestinal sistem temel olarak beslenme ve metabolik ürünlerin atılmasında önem taşımaktadır. Gastrointestinal sistemdeki sorunlar diğer birçok organı etkileyebilmekte ve uzun dönemde ciddi sağlık sorunlarına neden olabilmektedir. Çoğu zaman önemsenmeyen bu şikayetler için bireyler geçici çözümlere başvurabilmektedirler. Başvurulan bu geçici çözümler bilinçsizce ve kulaktan dolma, güvenilir olmayan kaynaklardan gelen duyumlarla olabilmekte ve bu da sağlık açısından risk taşımaktadır (11). Yapılan bir çalışmada katılımcıların bitkisel ürünler ile tedaviye yöneldikleri sağlık sorunlarının; en fazla bağırsak hastalığı ve vücut ağırlığını azaltmak olduğu belirtilmektedir (11). Brezilya'da yapılan popülasyon temelli bir araştırma, kadınların gastrointestinal semptomlarının 1.5 kat daha yüksek olduğu bildirilmiştir. Kadınların, erkeklere göre daha fazla olmak üzere

Tablo 5. Kullanılan bitkisel ürünleri temin etme yeri/şekli

\begin{tabular}{lcc|}
\hline & N & $\%$ \\
\hline Eczane & 53 & 27 \\
\hline Aktar (açıkta satılan ürünlerden) & 81 & 41.4 \\
\hline Aktar (ambalajı satılan ürünlerden) & 51 & 26 \\
\hline Internet & 3 & 1.5 \\
\hline Semt pazarı & 5 & 2.6 \\
\hline Temin etmem & 3 & 1.5 \\
\hline
\end{tabular}


haftada en az iki kez, mide ekşimesi, midede yanma hissi, asit yetersizliği, yutma zorluğu gibi yakınmaları olduğu saptanmıştır (12). Bizim çalışmamızda, çalışmaya katılan kadınların \%62.5'i, erkeklerin ise \%37.5'i gastrointestinal rahatsızlığı olduğunu bildirmiştir.

Yapılan bir çalışmada geleneksel ve tamamlayıcı tedavi uygulamalarına başvuran hastaların \%90.6'sı bitkisel karışımlar ve bitki çayları kullandıklarını belirtmişlerdir. Hastaların demografik özellikleri ile geleneksel tedavi kullanımları arasında istatistiksel olarak anlamlı fark bulunmamıştır (13). Bizim çalışmamızda da sindirim sistemi şikâyeti bulunan bireylerin \%53.8'i bu rahatsızlıklarında yardımcı besin ve bitkisel ilaç kullandıklarını, \%70'i ise kullanmadıklarını beyan etmişlerdir. Ancak, Gis şikâyeti olmadığı halde bitkisel ürün ve besin kullandığını belirten kişilerin de varlığı dikkat çekmektedir (\%46.2). Bu durum, Gis hastalıklarının farkında olan veya kronik Gis hastalığı olan kişilerin, hekim kontrolü altında ve farmakolojik tedavi aldıklarını, ancak akut Gis şikâyeti olanların ise geçici çözümler bulmaya çalıştıklarını düşündürmektedir. Bu çalışmada da GiS şikayeti bulunduğunu söyleyenlerin verdikleri yanıtlara göre mide yanması için en fazla maden suyu, elma, leblebi, süt, nane ve zencefil; şişkinlik için en fazla maden suyu, karbonat, yeşil çay, rezene ve kimyon; konstipasyon için en fazla, kuru kayısı, zeytinyağı, kuru incir, kavun, kekik suyu, salatalık ile birlikte su, keten tohumu; diyare için en fazla haşlanmış patates, kuru Türk kahvesi-limon, muz, kola, kuru çay, leblebi, yoğurt kullanımı görülmekteyken, sık yaşadığı Gis şikayeti olmadığı halde akut olarak yaşadığında besin ve bitkisel ürün kullanımı olduğunu belirten bireylerin de benzer şekilde kullanımları olduğu görülmüştür. Diğer yandan, çalışmaya katılanlar arasında GiS şikayetleri için ticari bitkisel ürün kullandığını beyan eden birey olmamıştır. Zengin bir diyet lifi olduğu bildirilen kimyon tohumu; besinlerin mide içerisinde uygun kıvam oluşturmasını sağlayarak, yetersiz sindirim sonucu oluşabilecek şişkinlik, gaz, diyare veya konstipasyon gibi sindirim sistemi sorunlarını engellemektedir. Tohumlarının çiğnenmesi sindirime yardımcı olsa da çay gibi tüketilmesinin en etkili ve doğru yol olduğu bildirilmiştir (14). Nane yağı ile yapılan çok sayıda klinik çalışma da; iyi tolere edildiği, ancak özafagus sfinkterin gevşemesine neden olarak asit reflüsüne neden olabileceği için teorik kaygılar bulunduğu bildirilmiştir (15). Kekik ise bileşiminde yüksek miktarda bulunan organik asitler ve flavonoidler barındırdığından, yüksek bir antioksidan aktiviteye sahip olarak değerlendirilmiştir (16). Bu nedenle oral olarak alınan kekik yağının bakteriyal ve viral enfeksiyonları iyileştirmede etkili olduğu belirtilmektedir $(15,17)$. Bu çalışmada da bireylerin, mide yanması, konstipasyon ve şişkinlik için kekik veya kekik suyu kullanımını belirttiği görülmektedir. Kro- nik böbrek yetmezliği olan hastaların beslenme durumunu iyileştirmeyi amaçlayan bir çalışmada 4 hafta boyunca günlük 60 ml zeytinyağı kullanımının konstipasyonu azalttığı, ancak müdahalenin sonlandırılmasından altı ay sonra konstipasyon şikayetlerinin tekrar başladığı bildirilmiştir (18). Semptomlar ayrıntılı olarak incelendiğinde de keten tohumuna göre zeytinyağının konstipasyon semptomlarının azaltılmasında daha etkili olduğu belirtilmiştir (19). Salatalık tohumlarından elde edilen ekstrenin antioksidan ve anti-ülser etkisi, sıçanlarda ülser modellemesi yapılarak çalışılmış, çalışma sürecinde yapılan ölçümler sonucu salatalık ekstraktının antioksidan aktivitesinin önemli bir anti-ülser potansiyeline sahip olduğu gösterilmiştir. Ekstratın fitokimyasal taraması, salatalık tohumlarında tanenlerin, proteinlerin, amino asitlerin, triterpenoidlerin, fitosterollerin ve karbonhidratların varlığını göstermektedir. Salatalık tohumlarının anti-ülser aktivitesi, tanen içeriğine bağlanmıştır (20). İshal önleyici özellik gösteren yeşil muz ve pektinin etkilerini değerlendirmek için, çocuklarda yeşil muz-pektin diyeti uygulanan bir araştırmada tedaviden önce ve sonra laktuloz-mannitol testiyle bağırsak geçirgenliği ve bütünlüğü belirlenmiştir. Yeşil muz ve pektinin anormal mukozal geçirgenliğini iyileştirdiği gösterilmiştir. İyileştirilmiş mukozal geçirgenlik, gaita kıvamında iyileşme ve dışkılama miktarında bir düşüşle eş zamanlı bir düzelme sağladığı ve bu etkilerle bağırsaktan absorbsiyonun regüle olduğu bildirilmiştir. Yeşil muz ve pektinin antidiyaretik etki gösterdiği mekanizmanın kolonik kısa zincirli yağ asitleri (SCFA) bütirat, asetat, propiyonat üretimine aracılık ettiği ve kolonik, tuz ve su emilimini uyardığı ileri sürülmektedir $(21,22)$. Kuru kayısının, mide kanserine yol açan Helicobacter pylori kaynaklı kronik atrofik gastrite karşı koruyucu olduğu gösterilmiştir (23).

Yetişkin bireylerin Gis şikayetlerinde biyolojik temelli uygulamaların sorgulandığı bu çalışmada katılımcıların \%41.4'ü, kullandıkları bitkisel ürünleri aktarlarda açıkta satılan toz, karışım, çay gibi ürünlerden yana kullandıklarını beyan etmişlerdir. Bu bitkisel ürünleri kullandığını bildirmediği halde bireylerin \%27'si hazır tablet, toz ya da şurup şeklinde eczanelerden temin etmekte olduğunu, \%26'sı da yine ambalajlanmış toz, karışım, çay şeklinde temin ettiğini belirtmiştir. Bitkiler veya bitkisel ürünler açık havaya maruz kaldıklarından hem tozlarla taşınan E. coli, Salmonella spp., B. cereus, C. perfiringens gibi patojen mikroorganizmalar hem de haşerelerin ve diğer canlıların çeşitli atıkları ile kontamine olabilmektedirler. Kontamine olmuş bitkiler de oral alım sonucu besin zehirlenmelerine neden olabilmekte ve sağlık üzerinde tehlike oluşturmaktadır (24). Çalışmalara katılanların bir kısmı hekim önerisiyle bitkisel ürün kullanımının daha doğru olduğunu belirtirken, bir kısmı da bitkisel tedavinin ilaç- 
lardan daha etkili olduğunu belirtmektedir. Bu durum bitkisel ürünlerle ilgili bilgi eksikliğinin bulunduğunu göstermektedir $(25,26)$. ABD'de 1000 üniversite öğrencisi üzerinde yapılan bir çalışma ile tutarlı olarak; aile, bitkisel ürün kullanımı ile ilgili önemli bir bilgi kaynağı olarak bulunmaktadır (27). Bu çalışmada ise tamamlayıcı tedavide bitkisel kaynakların kullanım bilgi kaynağı olarak bireylerin \%29.1'i 1. sırada aileyi tercih ederken, \%32.6'sı bilgi kaynağı olarak 1. sırada doktorları tercih ettiğini belirtmişlerdir. Bitkisel ürünlerin kullanımı hakkında aile tavsiyesine güvenmek, kullanıcılar arasında genel bir bilimsel bilgi ve sorgulama eksikliğini göstermektedir. Bitkisel ürünlerin hastalıkların tedavisinde kullanımları insanlık kadar eski olsa da geleneksel kullanımlar bu ürünlerin etkinliği için bir ölçüt olarak kabul edilmemektedir (28). Bu tür ürünlerin güvenli kullanımı arkadaş veya aile tavsiyeleri yerine, kullanım sonuçlarını gösteren yeterli bilimsel kanıtların temeline dayandırımalıdır. ABD'de genç yetişkin hastalar üzerinde yapılan bir başka çalışmada da, bireylerin sadece \%24'ünün kullandıkları bitkisel ürünleri sağlık profesyonellerine danıştığını gösterilmiştir (29). Türkiye'de bir gastroenteroloji polikliniğine başvuran hastalarda, geleneksel tedavi olarak bitki kullanımının insidansını içeren çalışmada, gastrointestinal rahatsızıkları olan hastalarda geleneksel tedavi olarak bitkileri tercih etme oranının \%36.6 olduğu belirtilmektedir (30). Bizim çalışmamızda ise gastrointestinal rahatsızlığı olan bireylerin \%53.8'i geleneksel tedavide besin ve bitki/bitkisel ürün tercih ettiğini bildirmişlerdir. Bitkisel ilaçların kullanımı ile ilgili önemli bir endişe onların güvenlik, dozaj ve toksisite profilidir. Dünya çapında, bitkisel ürün kullanımında çeşitli toksisite vakaları bildirilmektedir. Bunların en önemlisi, kullanan kadınlar arasında böbrek yetmezliğinin gelişmesidir. Bitkisel ürünlerin standardizasyonu; kullanılan bitkinin türüne, kimyasal yapısına, yetiştirme koşullarına, hasat dönemlerine ve depolama koşullarına bağlı olarak farklılık göstermesi nedeniyle zor olmasının yanında uzun zaman almaktadır (31). Ancak, bitkisel ürünlerin kullanımı; medyadaki yaygın tanıtımlar, reklamlar ve asısız sağlık beyanı iddiaları nedeniyle artmakta ve sıklıkla toksik cevaplar ortaya çıkmaktadır. Bitkilerdeki biyoaktif bileşikler, halen ve tam olarak tanımlanamamıs, toksisite ve yan etkiler konusunda yeterli bilgiler sağlanamamıştır (32).

Genel beslenme alıskanlıklarında, bireylerin yemek yeme hızı ve dışardan yeme sıklığı ile sindirim sistemi hastalıkları bulunma durumlarına bakıldığında yemek yeme hızı çok hızlı olan 21 bireyin 19'unun (\%90.5) sık yaşadığı sindirim sistemi rahatsızlığı olduğu görülmektedir. Dışardan yeme sıklığına göre ise her gün dışardan yediğini belirten 18 bireyin $15^{\prime}$ inin (\%83.3) sık yaşadığı sindirim sistemi hastalığı olduğu görülmektedir. Bu farklar istatistiksel olarak anlamlı bulunmuştur ( $p<0.05)$. Aynı zamanda bireylerin su tüketim ortalamalarının 1700 ml olduğu görülmektedir. 18-64 yaş arası erişkinlerde yetersiz su tüketiminin daha yüksek beden kitle indeksi (BKi) ve obezite ile ilişkili olduğu görülmüştür. Bu da dolaylı olarak gastrointestinal sistem ile ilişkili olduğundan; su tüketiminin, 70 kg'lık yetişkin bir erkeğe ve 58 kg'lık yetişkin bir kadına dayanarak, yetişkin kadınlar için $2.2 \mathrm{l} /$ gün ve erkekler için 2.5 I/gün su tüketimine intiyacı olduğu belirtilmektedir (33).

Genel beslenme alışkanlıklarına göre Gis şikâyeti olan bireylerin 75'i (\%38.3) nadiren de olsa öğün atladığını belirtmektedir. Obez bireylerle yapılan bir çalışmada atlanan öğünlerin obeziteye neden olmasından dolayı, dolaylı olarak gastroözofageal reflü ile ilişkili olabileceği bildirilmiştir (34). Gis şikâyeti olan 51 (\%26) kişinin nadiren de olsa öğün atladığı görülmektedir. Gis şikâyeti olan 51 (\%26) kişinin öğün saatleri de düzensizdir. Gis şikâyeti olan 73 kişinin (\%37.2) cips, kola, çikolata vb. gibi atıştırmalık alışanlığı bulunmaktadır. Yapılan bir çalışmada zararlı atıştırmalık tüketiminin hem asit-peptik hastalığına neden olduğu hem de H. pylori görülme sıklığını arttırdığı bildirilmiştir (35).

Sonuç olarak, bu çalışmada gastrointestinal rahatsızlıklarda bitkisel ürünler ile bazı besinlerin kullanımına yönelik tutumlar bulunsa da tanı almış kişilerin öncelikle medikal tedaviyi tercih ettikleri görülmüştür. Toplumun geleneksel ve tamamlayıcı tedavi, alternatif tedavi konularında bilgilendirilmesi gerekmektedir. Diğer yandan toplum bireylerine hastalıklar, besinler ve bitkisel ürünlerin etkileşimleri konusunda da doğru kaynaklardan güvenilir bilgi aktarımının da hastalıkların tedavi sürecinde olumlu etkileri olacağı düşünülmektedir.

Bitkisel ürün kullanımının sadece sağlıkla alakalı bir durum olmadığını ve bu ürünlerin kullanımının sosyal ve kültürel boyutu da düşünülerek, başta sağlık profesyonelleri tarafından durum ciddiye alınmalı ve gerekli bilgilendirme yapılarak, bireylerin sağlığının zarar görmesi engellenmelidir. Aynı zamanda bu konuda kitle iletişim araçları ile bireylerin rahatlıkla ulaşabildiği bilimsellikten uzak bilgileri engelleme hususunda çalışmalara gidilmelidir. Ayrıca bitkisel ürünlerin etkinlik, güvenlik ve maliyet açısından da değerlendirilmesi ve daha fazla bilgi edinilmesi gerekmektedir. Bu alanda ilerlemenin önündeki en büyük engeller, araştırma fonlarının eksikliği ve yeni klinik çalışmaların tasarlanmasında titiz metodolojilerin daha az kullanılmasıdır. Hem klinik öncesi hem de klinik çalışmalara dayanarak gastrointestinal hastalıkların tedavisinde bazı bitkiler için önemli kanıtlar görülebilmektedir ancak, klinik denemelerin çoğu küçük ya da optimal olmayan metodolojilerdir. Bazı çalışmaların çelişkili sonuçları, doz- 
ların belirlenememesi, bileşenler ve sonuç ölçütleri için standardizasyon eksikliği bu ürünlerin güvenli kullanımını sağlayamamaktadır. Bu nedenlerle birlikte sindirim sistemi rahatsızlıkları için, etraftan duyulan, medya veya diğer kitle iletişim araçları üzerinden etkinliği kanıtlanmamış, daha önce duyulmamış bitkisel ürünler veya bitkiler kullanmak yerine fiziksel aktiviteyi arttırmak, dengeli ve düzenli beslenmek, her besin ögesinden yeteri kadar almak, yeterli su tüketimini sağlamak, doğru pişirme tekniklerini kullanmak, beslenme alışkanlıklarını düzenlemek gibi basit yaşam tarzı değişiklikleri ile üstesinden gelmek sağlıklı bir yaşam için temel oluşturacaktır. Uygun bilgi sistemle- rinin, hizmetlerinin ve desteğinin sağlanması, yetişkinler tarafından yanlış kullanım ve gelişi güzelliğin önlenmesi için birincil sağlık hizmetleri sistemi çerçevesinde bir düzenleme sağlanması gerekmektedir. Ayrıca bütün bunlar dışında doğrudan veya dolaylı olarak psikolojik durum ile de ilişkili olan gastrointestinal sistem hastalıkları psikiyatri konsültasyonu istenen tıbbi hastalıklar arasında birinci sırada yer almaktadır. Bütün bu yaşam tarzı değişiklikleriyle birlikte, bireylerin emosyonel durumları da değerlendirilerek yeni çalışmalar yapılması gerekmektedir.

\section{"Tüm yazarlar herhangi bir çıkar çatışması olmadığını kabul ederler."}

\section{KAYNAKLAR}

1. Akbulut G, Çiftçi $H$, Yıldız E. Sindirim Sistemi Hastalıkları ve Beslenme Tedavisi. 2008. Erişim:http://beslenme.gov.tr/content/ files/yeterlibeslenme/hastaliklarda_beslenme/c8.pdf Erişim Tarihi: 1.07.2018.

2. Alpar F. Vücut geliştirme sporcularında beslenme, fiziksel aktivite ve besin takviyesi kullanım durumlarının incelenmesi. Hacettepe Üniversitesi Sağlık Bilimleri Enstitüsü, Yüksek Lisans Tezi, 2011, Ankara.

3. Bkope ET, Kellerman RD. The digestive system. In: Bope ET (ed). Conn's Current Therapy 2016. Philadelphia, PA: Elsevier Saunders; 2016: Chap 8.

4. Carlson MJ, Moore CE, Tsai CM, Shulman RJ, Chumpitazi BP. Child and parent perceived food- induced gastrointestinal symptoms and quality of life in children with functional gastrointestinal disorders. J Acad Nutr Diet 2014;114:403-13.

5. Carey S, Ferrie S, Young J, Allman-Farinelli M. Long-term nutrition support in gastrointestinal disease-a systematic review of the evidence. Nutrition 2012;28:4-8.

6. Akaslan A, Fonksiyonel gastrointestinal hastalıklar tanısında kulIanılan Roma III Kriterlerinin Türkçeye uyarlanması ve geçerlik güvenilirliği. Uzmanlık tezi, Ege Üniversitesi Tıp Fakültesi, İzmir, 2011.

7. T.C. Sağlık Bakanlığı Geleneksel ve Tamamlayıcı Tıp Uygulamaları Daire Başkanlığı. Erişim : https://getatportal.saglik.gov.tr/ TR,24683/geleneksel-ve-tamamlayici-tip-nedir.html Erişim Tarihi 2.03.2019.

8. Özçelik G, Toprak D. Why is phytotherapy preferred? Ankara Med J 2015;15:48-58.

9. Kasper Dennis L, Braunwald E, Hauser S, et al. Harrison's Principels of Internal Medicine. 16th ed. New York: McGraw - Hill Medical Publishing Division: 1746-1762,2005.

10. Illiaz R, Kaymakoğlu S. Fonksiyonel gastrointestinal sistem hastalıkları ve otilonyum bromür-simetikon kombinasyonu. Güncel Gastroenteroloji 2016;20:409-14.

11. Yilmazel G, Naçar M. Herbal products: utilization, knowledge and attitudes of Turkish adults. Int J Basic Clin Pharmacol 2018;5:242631.

12. do Rosário Dias de Oliveira Latorre M, Medeiros da Silva A, Chinzon D, Eisig JN, Dias-Bastos TR. Epidemiology of upper gastrointestinal symptoms in Brazil (EpiGastro): a population-based study according to sex and age group. World J Gastroenterol 2014;20:17388-98.

13. Arı E, Yılmaz V. Tamamlayıcı ve alternatif tıp kullanımına yönelik tutum ve davranışların önerilen bir yapısal model ile araştırılması. Uluslararası Alanya İşletme Fakültesi Dergisi 2016;8:13-24.

14. 6 Science Backed Health Benefits of Caraway Seeds- 2018 Research. Erişim: https://healthyfocus.org/health-benefits-of-caraway-seeds/Erişim tarihi: 06-07-2018

15. Hawthorn M, Ferrante J, Luchowski E, et al. The actions of peppermint oil and menthol on calcium channel dependent processes in intestinal, neuronal and cardiac preparations. Aliment Pharmacol Ther 1988;2:101-18

16. Dragland S, Senoo H, Wake K, Holte K, Blomhoff R. Several culinary and medicinal herbs are important sources of dietary antioxidants. J Nutr 2003;133:1286-90.

17. Barrett S. Regulatory Actions against Michael Teplitsky, M.D. Quackwatch, 13 June 2005. Retrieved 2 November 2010. (https:// quackwatch.org/11ind/teplitsky/)

18. Pérez VB, Gil-Cunquero JM, Borrego FJ, et al. Preliminary study on efficacy and tolerance of a" coupage" of olive oil in patients with chronic kidney disease. Nutritonal evaluation. Nefrología 2007;27:472-81

19. Ramos Cl, de Lima AFA, Grilli DG, Cuppari L. The short-term effects of olive oil and flaxseed oil for the treatment of constipation in hemodialysis patients. J Ren Nutr 2015;25:50-6.

20. Gill NS, Garg M, Bansal R, et al. Evaluation of antioxidant and antiulcer potential of Cucumis sativum L. seed extract in rats. Asian Journal of Clinical Nutrition 2009;1:131-8.

21. Rabbani GH, Albert MJ. Rahman H, Chowdhury AK. Short-chain fatty acids inhibit fluid and electrolyte loss induced by cholera toxin in proximal colon of rabbit in vivo. Dig Dis Sci 1999;44:1547-53. 